Check for updates

Cite this: RSC Adv., 2018, 8, 39274

Received 24th August 2018

Accepted 20th November 2018

DOI: $10.1039 / c 8 r a 07088 a$

rsc.li/rsc-advances

\section{Synergistic and simultaneous biosorption of phenanthrene and iodine from aqueous solutions by soil indigenous bacterial biomass as a low-cost biosorbent}

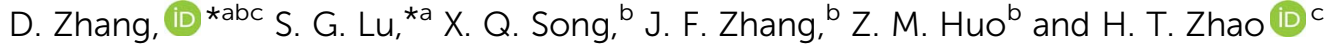

The removal of phenanthrene and iodine from aqueous solutions in single and binary systems by inactivated soil indigenous bacterial biomass (SIBB), as well as affecting factors, were evaluated. Sorption kinetic and isotherm studies were carried out to investigate the synergistic effects of phenanthrene and iodine. Optimal parameters for the biosorption process included a solution $\mathrm{pH}$ of 6.0 and biosorbent dosage of $0.75 \mathrm{~g} \mathrm{~L}^{-1}$. The ionic strength significantly decreased the biosorption of both phenanthrene and iodine in single conditions, while no obvious influences were found in the binary conditions. A pseudo-secondorder model was well fitted to the kinetic biosorption data for both phenanthrene and iodine. The results showed that the presence of co-solute accelerated the biosorption processes and the pseudo-secondorder biosorption rates $\left(k_{2}\right)$ for phenanthrene and iodine increased from 0.005441 to $0.009825 \mathrm{~g}$ $\mathrm{mg}^{-1} \mathrm{~min}^{-1}$ and from 0.000114 to $0.000223 \mathrm{~g} \mathrm{mg}^{-1} \mathrm{~min}^{-1}$, respectively. The SIBB showed strong affinity with both phenanthrene and iodine, with a partition coefficient $K_{\mathrm{d}}$ (Linear model) of $6892.4 \mathrm{~L} \mathrm{~kg}^{-1}$ for phenanthrene and affinity parameter $K_{\mathrm{L}}$ (Langmuir model) of $232500 \mathrm{~L} \mathrm{~kg}^{-1}$ for iodine. The presence of co-solute illustrated a synergistic effect on the biosorption of phenanthrene and iodine due to intermolecular forces between phenanthrene and iodine, enhancing the $K_{d}$ of $34.7 \%$ for phenanthrene and $K_{\mathrm{L}}$ of $107.0 \%$ for iodine, respectively. The results suggested that SIBB was an effective material for the simultaneous biosorption of phenanthrene and iodine from aqueous solutions.

\section{Introduction}

Contaminants harmful to the health of present and future generations involve nuclear fission products such as iodine radioisotopes. Iodine radioisotopes have been released into our environment due to anthropogenic activities such as the nuclear energy industry, nuclear accidents and wastewater discharge containing radioactive iodine. ${ }^{1,2}$ Iodine is potentially one of the most mobile radioisotopes ${ }^{3,4}$ and easily reaches the biosphere ${ }^{5}$ because of its weak affinity with many geological materials, low-organic-content soils and sediments. Therefore, iodine is potentially acutely and chronically toxic due to bioaccumulation through the food chain and may subsequently affect human health adversely. ${ }^{6,7}$ It is useful to understand the interactions between iodine and natural or artificial materials of the environment in contact with surface waters and groundwater, as well as co-existing pollutants.

${ }^{a}$ College of Environmental \& Resource Sciences, Zhejiang University, Hangzhou, Zhejiang 310058, China. E-mail: zhangdong@hdu.edu.cn; lusg@zju.edu.cn; Tel: +86-571-86919158

${ }^{b}$ Zhejiang Wulong Chemical Industrial Stock Co. Ltd, Deqing, Zhejiang 313201, China ${ }^{c}$ College of Materials and Environmental Engineering, Hangzhou Dianzi University, Hangzhou, Zhejiang 310018, China
Several recent studies reported that aromatic structures in natural organic matter (NOM) played an important role in the sorption of iodine to soil and/or sediment. ${ }^{4,8,9}$ Aromatic carbon in NOM participated in the oxidation of iodine to some form of intermediates, facilitating the formation of aromatic carboniodine bonds rather than aliphatic carbon-iodine bonds. ${ }^{8,10}$

In addition, hydrophobic organic compounds (HOCs) are ubiquitous toxic contaminants, ${ }^{11,12}$ which can be highly likely to co-exist with iodine in soil and aquifer environments near nuclear power plants. These contaminants are highly transferable and easily to interact with soil particles, biota and microorganisms. ${ }^{4,5}$ Many HOCs, such as polycyclic aromatic hydrocarbons (PAHs) and polychlorinated biphenyls (PCBs), contain two or more aromatic structures. These co-existing pollutants may exhibit the same, or at least similar, interactions with iodine as NOM do. The formation of aromatic carbon-iodine bonds could affect the transport, fate, and removal of iodine and co-existing HOC pollutants, making it much more complex to evaluate their environmental behaviours and ecological risks. However, little information is available about the interactions of iodine and aromatic containing contaminants, as well as the influence on subsequent sorption and removal of the co-existing pollutants. 
To overcome (or at least limit the contribution of) this risk, it would be useful to find efficient scavengers for iodine, as well as HOCs. The use of natural biomaterials (served as adsorbents) is considered promising and the most attractive alternative due to their easy handling, versatility, costeffectiveness, efficiency, low-selectivity and relative abundance compared with conventional techniques. ${ }^{13-15}$ Studies have reported that dead or metabolically inactive biomass materials were used as successful biosorbents for the treating or removal of dyes, ${ }^{16-19}$ heavy metals, ${ }^{20-23}$ HOCs $^{24-26}$ and radioactive elements such as uranium $^{27,28}$ from aqueous solutions. Several mechanisms were also proposed and summarized as follows: ${ }^{29}$ (1) electrostatic binding for some cationic metals, dyes and radioactive elements due to negative groups in biosorbents; ${ }^{\mathbf{1 6 , 2 7 , 3 0}}$ (2) hydrophobic interactions and partitioning for hydrophobic organic compounds; $;^{\mathbf{2 6 , 3 1}}$ (3) specific molecular-level interactions such as cation- $\pi$ interactions; ${ }^{32}$ and (4) deposition on the cell surface or within the cell wall structures. ${ }^{15}$ Simultaneous removal of metal-metal ${ }^{20}$ and metal-organic compounds ${ }^{33}$ were also reported. However, to our knowledge, limited information is available for the biosorption of iodine, as well as the synergistic influence of aromatic compounds.

Therefore, the main objectives of this study were to evaluate the biosorption capability of a low-cost soil indigenous bacterial biomass (SIBB) for the simultaneous removal of phenanthrene (typical PAHs) and iodine as a model of combined pollutants by (1) examining the biosorption potential of phenanthrene and iodine onto SIBB in single and binary systems, and (2) optimizing the parameters affecting the biosorption process.

\section{Materials and methods}

\subsection{Biosorbent and sorbate preparation}

The biosorbent was obtained from physically and thermally inactivated soil indigenous bacterial biomass as described in previous works. ${ }^{31,34}$ The indigenous bacteria were isolated from soil in an agricultural field of Zhejiang, China, near the Qinshan Nuclear Power Plant and then cultured in Lysogeny Broth. After harvest, bacteria were washed three times with deionized water to remove any remaining culture media. To obtain inactive biomass, indigenous bacteria were dried for $24 \mathrm{~h}$ at a temperature of $70{ }^{\circ} \mathrm{C}$ following mechanical grinding. The surface properties of SIBB material were measured according to our previous work. ${ }^{34}$ The specific surface of the biosorbent was determined by a gas sorption analyzer (NOVA1200, Quantachrome Corp., USA). The biosorbent was further characterized using Fourier transform infrared spectroscopy (FTIR, Shimadzu 8400S, Kyoto, Japan).

Stable iodine and phenanthrene were selected as representative iodine species and HOCs and were purchased from Aladdin Reagent Co. (China) with purities $>99.0 \%$. Stock solutions $\left(1000 \mathrm{mg} \mathrm{L}^{-1}\right.$ for phenanthrene in methanol and $200 \mathrm{mg} \mathrm{L}^{-1}$ for iodine in deionized water) were prepared and stored in amber glass bottles at $4{ }^{\circ} \mathrm{C}$. Working solutions in the range of $0-1.0 \mathrm{mg} \mathrm{L}^{-1}$ for phenanthrene and $0-200 \mathrm{mg} \mathrm{L}^{-1}$ for iodine in single and binary systems were prepared by serial dilution. $\mathrm{NaOH}\left(0.1 \mathrm{~mol} \mathrm{~L}^{-1}\right)$ and/or $\mathrm{HCl}\left(0.1 \mathrm{~mol} \mathrm{~L}^{-1}\right)$ were used to adjust the $\mathrm{pH}$ of solutions. The inorganic reagents used for the growth of the microorganisms such as tryptone, yeast extract, and sodium chloride, were of analytical grade (Aladdin Reagent Co., China).

\subsection{Sorption tests and analytical methods}

Batch sorption experiments were carried out in a temperaturecontrolled shaker at $150 \mathrm{rpm}$ at $25{ }^{\circ} \mathrm{C}$, and tubes were prepared in duplicate, as described in our previous work. ${ }^{31} \mathrm{In}$ the kinetic and isotherm sorption experiments, a certain amount of sorbents, $15 \mathrm{mg}$ for SIBB, were weighted into $22 \mathrm{~mL}$ centrifuge tubes with $20 \mathrm{~mL}$ single iodine, single phenanthrene and their binary solutions. The concentrations of iodine and phenanthrene covered the range of $0-200 \mathrm{mg} \mathrm{L}^{-1}$ and $0-$ $1.0 \mathrm{mg} \mathrm{L}^{-1}$, respectively. Control treatments without biosorbents were prepared to account for the possible solute loss by handling and other possible ways. Single-factor biosorption experiments were also conducted, and other factors were adjusted to suitable conditions: biosorbent dosage at $0.25,0.5$, 0.75, 1.0, and $1.25 \mathrm{~g} \mathrm{~L}^{-1}$; ionic strength $\left(\mathrm{CaCl}_{2}\right)$ at 0, 0.1, 0.2, 0.3, 0.4 , and $0.5 \mathrm{~mol} \mathrm{~L}^{-1}, \mathrm{pH}$ at 3, 4, 5, 6, 7, 8, 9, and 10; and biosorption time of $60,90,120,180,240,480,720,960,1200$, and 1440 min in single and binary conditions. The sorption equilibrium time was set up according to the biosorption kinetics experiments. At the equilibrium time, after being centrifuged for $20 \mathrm{~min}$ at $4000 \mathrm{~g}$, the supernatants were filtrated by $0.22 \mu \mathrm{m}$ filter membranes (ANPEL Co., Ltd., China).

The concentration of phenanthrene in the aqueous phase was determined using HPLC (Agilent 1260) equipped with a 4.6 $\times 250 \mathrm{~mm}$ Eclipse $\mathrm{PAH}$ column and a fluorescence detector using a methanol and water mixture (v/v, $95: 5)$ as mobile phase

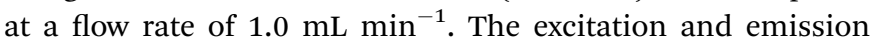
wavelengths of phenanthrene were 244 and $360 \mathrm{~nm}$, respectively. The method quantification limit value for phenanthrene was $3.39 \mu \mathrm{g} \mathrm{L}^{-1}$, and the relative standard deviation for phenanthrene determination was $0.23 \%$. The determination of iodine followed the method described by Madrakian et al..$^{35}$ and the concentration was measured using a spectrophotometer (Shimadzu UV-2600) at a wavelength of $460 \mathrm{~nm}$.

The removal efficiency of phenanthrene and iodine by SIBB was determined using the following equation:

$$
\text { Removal efficiency }(\%)=\left(1-\frac{C_{\mathrm{i}}}{C_{t}}\right) \times 100 \%
$$

where $C_{\mathrm{i}}$ and $C_{t}\left(\mathrm{mg} \mathrm{L}^{-1}\right)$ represent the initial and final (at any time $t$ ) concentration of phenanthrene or iodine, respectively. The sorption capacity of bacterial biomass for phenanthrene or iodine at time $t, Q_{t}\left(\mathrm{mg} \mathrm{kg}^{-1}\right)$, is obtained as follows:

$$
Q_{t}=\frac{\left(C_{\mathrm{i}}-C_{t}\right) \times V}{m}
$$

where $V(\mathrm{~mL})$ is the volume of the solution and is equal to $20 \mathrm{~mL}$ in the present study; and $m(\mathrm{mg})$ represents the mass of biosorbent, $15 \mathrm{mg}$ for SIBB is used in the present study. 


\subsection{Kinetic sorption models}

To determine the biosorption kinetics, the obtained dynamic experimental data was fitted with several kinetic models, such as the Morris-Weber model, Lagergren model and pseudosecond-order model. The Morris-Weber model ${ }^{36}$ can be expressed as follows:

$$
Q_{t}=K_{\mathrm{id}} \sqrt{t}+C
$$

where $Q_{t}\left(\mathrm{mg} \mathrm{g}^{-1}\right)$ is the sorbed phenanthrene or iodine at time $t$. The values of the rate constant of Morris-Weber $\left(K_{\mathrm{id}}\right)$ are calculated using the slope of the linear plot.

The Lagergren pseudo-first-order model, which was the earliest known equation to explain the adsorption rate based on the adsorption capacity, was also used to stimulate the sorption kinetic data. ${ }^{37}$ The equation is generally expressed as follows:

$$
\lg \left(Q_{\mathrm{e}}-Q_{t}\right)=\lg Q_{\mathrm{e}}-k_{1} t
$$

where $Q_{\mathrm{e}}$ is the biosorbed amounts of phenanthrene or iodine at equilibrium time $\left(\mathrm{mg} \mathrm{g}^{-1}\right)$, and $k_{1}$ is the rate constant $\left(\min ^{-1}\right)$. The plot of $\lg \left(Q_{\mathrm{e}}-Q_{\mathrm{t}}\right)$ versus $t$ gives a straight line for the pseudo-first-order sorption kinetics. The values of the pseudo-first-order rate constant $k_{1}$ are obtained from the slopes of the straight lines.

The non-linear form of the pseudo-second-order model can be written as follows according to Ho: ${ }^{38,39}$

$$
\frac{t}{Q_{t}}=\frac{1}{k_{2} Q_{\mathrm{e}}{ }^{2}}+\frac{1}{Q_{\mathrm{e}}} t
$$

where $k_{2}$ is the pseudo-second-order rate constant ( $\mathrm{g}$ $\left.\mathrm{mg}^{-1} \min ^{-1}\right)$.

\subsection{Isothermal sorption models}

The Langmuir, Freundlich, linear, D-R and Temkin models were used to describe the isothermal sorption of phenanthrene and iodine in single and binary systems by the bacterial biomass. The Langmuir isotherm is represented as:

$$
\frac{C_{\mathrm{e}}}{Q_{\mathrm{e}}}=\frac{1}{Q_{\mathrm{m}} K_{\mathrm{L}}}+\frac{C_{\mathrm{e}}}{Q_{\mathrm{m}}}
$$

where $C_{\mathrm{e}}$ and $Q_{\mathrm{e}}$ are the equilibrium concentration $\left(\mathrm{mg} \mathrm{L}^{-1}\right)$ and adsorption capacity $\left(\mathrm{mg} \mathrm{g}^{-1}\right)$ of phenanthrene or iodine on the bacterial biomass, respectively, at equilibrium conditions. The isotherm constants $Q_{\mathrm{m}}$ and $K_{\mathrm{L}}$ are the maximum adsorption capacity for monolayer coverage $\left(\mathrm{mg} \mathrm{g}^{-1}\right)$ and the coefficient related to the affinity between the sorbent and the sorbate $\left(\mathrm{L} \mathrm{mg}^{-1}\right)$, respectively.

The logarithmic form of the Freundlich model (original form: $\left.Q_{\mathrm{e}}=K_{\mathrm{F}} C_{\mathrm{e}}{ }^{1 / n}\right)$ is used to calculated the Freundlich parameters and is expressed as shown in the following equation:

$$
\log Q_{\mathrm{e}}=\log K_{\mathrm{F}}+\frac{1}{n} \log C_{\mathrm{e}}
$$

where $Q_{\mathrm{e}}$ is the amount adsorbed per unit weight of sorbent (mg $\left.\mathrm{kg}^{-1}\right) ; C_{\mathrm{e}}$ is the equilibrium concentration $\left(\mathrm{mg} \mathrm{L}^{-1}\right) ; K_{\mathrm{F}}[(\mathrm{mg}$ $\left.\mathrm{kg}^{-1}\right) \cdot\left(\mathrm{mg} \mathrm{L}^{-1}\right)^{-1}$, equal to $\mathrm{L} \mathrm{kg}^{-1}$ ] and $n$ (dimensionless) are the
Freundlich isotherm constants, describing the sorption capacity and the isotherm curvature, respectively.

The Linear isotherm model is also used to estimate the sorption of phenanthrene and iodine onto SIBB. The linear model is described as the form of the following equation:

$$
Q_{\mathrm{e}}=K_{\mathrm{d}} C_{\mathrm{e}}
$$

where $K_{\mathrm{d}}$ is the distribution coefficient of sorbate (phenanthrene or iodine) between water and sorbent $\left(\mathrm{L} \mathrm{kg}^{-1}\right)$.

The Dubinin-Radushkevich (D-R) isotherm model is applied to the data to deduce the heterogeneity of the surface energies of adsorption and the characteristic porosity of the biosorbent. The linear form of the $\mathrm{D}-\mathrm{R}$ model is given as follows:

$$
\ln Q_{\mathrm{e}}=\ln X_{\mathrm{m}}-\beta F^{2}
$$

where $F$ can be calculated by

$$
F=R T \ln \left(1+\frac{1}{C_{\mathrm{e}}}\right)
$$

where $Q_{\mathrm{e}}$ is the experimental adsorption capacity $\left(\mathrm{mol} \mathrm{g}^{-1}\right) ; F$ is the Polanyi sorption potential; $R$ is the gas constant $\left(8.314 \mathrm{~J} \mathrm{~K}^{-1}\right.$ $\left.\mathrm{mol}^{-1}\right) ; C_{\mathrm{e}}$ is the concentration of phenanthrene or iodine at equilibrium ( $\mathrm{mol} \mathrm{L}^{-1}$ ); and $T$ is the absolute temperature (298 $\mathrm{K})$. The D-R isotherm constants $X_{\mathrm{m}}$ and $\beta$ are the calculated maximum adsorption capacity $\left(\mathrm{mol} \mathrm{g}^{-1}\right)$ and the activity coefficient $\left(\mathrm{mol}^{2} \mathrm{~J}^{-2}\right)$ related to adsorption mean free energy $(\mathrm{kJ}$ $\mathrm{mol}^{-1}$ ), respectively. The mean sorption energy $E$, which is defined as the free energy transfer of $1 \mathrm{~mol}$ of the solute from infinity on the surface of the sorbent, can be calculated by:

$$
E=\frac{1}{\sqrt{-2 \beta}}
$$

The Temkin isotherm model suggests an equal distribution of binding energies over a number of exchange sites on the surface. The linear form of the Temkin isotherm can be written as:

$$
Q_{\mathrm{e}}=B \ln K_{\mathrm{T}}+B \ln C_{\mathrm{e}}
$$

where $B$ is equal to $R T / b$ and corresponds to the heat of sorption, with $R$ being the universal gas constant $\left(8.314 \mathrm{~J} \mathrm{~mol}^{-1} \mathrm{~K}^{-1}\right)$ and $T$ being the absolute temperature in Kelvin $(298 \mathrm{~K}) . b$ is the variation of the adsorption energy $\left(\mathrm{J} \mathrm{mol}^{-1}\right) ; K_{\mathrm{T}}$ is the equilibrium binding constant; and $C_{\mathrm{e}}$ and $Q_{\mathrm{e}}$ are the equilibrium concentration $\left(\mathrm{mol} \mathrm{L}{ }^{-1}\right)$ and sorption capacity $\left(\mathrm{mol} \mathrm{kg}{ }^{-1}\right)$, respectively.

\section{Results and discussion}

\subsection{Biosorbent characterization}

Fig. 1 showed the FTIR spectrum of the biosorbent used in the present study. The peak assignments of bacterial biomass were as follows. At $980 \mathrm{~cm}^{-1}$, the $=\mathrm{C}-\mathrm{H}$ stretching of unsaturated hydrocarbons was observed. Complementary information could 


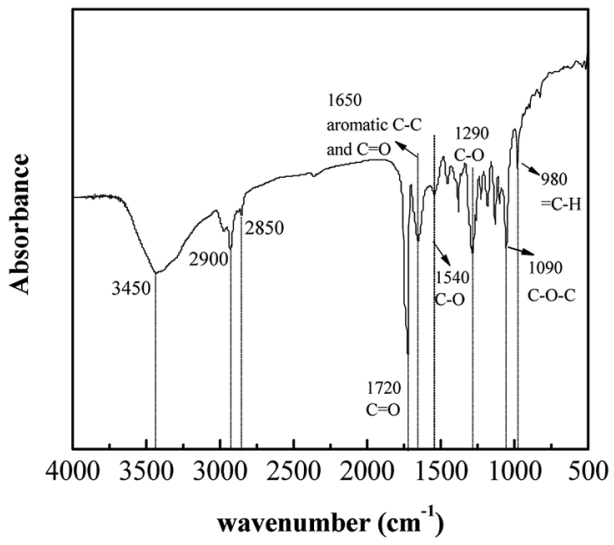

Fig. 1 The FTIR spectrum of bacterial biomass.

be deduced from the bands between 1200 and $900 \mathrm{~cm}^{-1}$, where the $\mathrm{C}-\mathrm{O}-\mathrm{C}$ and $\mathrm{C}-\mathrm{O}-\mathrm{P}$ functional groups were observed. The region between 1250 and $1200 \mathrm{~cm}^{-1}$ exhibited the $>\mathrm{P}=\mathrm{O}$ double-bond stretching vibrations. ${ }^{26}$ The bands at $1290 \mathrm{~cm}^{-1}$ and $1540 \mathrm{~cm}^{-1}$ were dominated by $\mathrm{C}-\mathrm{O}$ stretching of phenolic compounds and the amid II, respectively. The $\mathrm{C}-\mathrm{C}$ and $\mathrm{C}=\mathrm{O}$ of aromatic carbons asymmetric stretching frequency could be determined near $1650 \mathrm{~cm}^{-1}$. A characteristic peak at $1720 \mathrm{~cm}^{-1}$ was formed due to the vibrational $\mathrm{C}=\mathrm{O}$ of $-\mathrm{COOH}$ stretching frequency. A cluster of bands at the range of $3000-2850 \mathrm{~cm}^{-1}$ referred to saturated aliphatic groups (e.g., $-\mathrm{CH}_{3},-\mathrm{CH}_{2}-$ ). A broad and strong band at approximately $3450 \mathrm{~cm}^{-1}$ represented the symmetric stretching vibration from water molecules. ${ }^{26}$ The results confirmed that the bacterial surface was abundant with carboxyl, phosphate, amino groups, saturated and unsaturated aliphatic carbons and aromatic structures.

The specific surface area determined by the BET method was $1.43 \mathrm{~m}^{2} \mathrm{~g}^{-1}$, which was quite small but comparable with other research. ${ }^{17}$

\subsection{Biosorption of phenanthrene and iodine by SIBB in single and binary systems}

Effect of biosorbent dosage. Biosorbent dosage determines the number of active sites for pollutant binding, and it greatly affects the biosorption capacity and efficiency. In Fig. 2a, with the increasing dosage ( 0.25 to $1.25 \mathrm{~g} \mathrm{~L}^{-1}$ ), the biosorption efficiency escalated from $60.65 \%$ to $78.78 \%$ for phenanthrene and from $34.49 \%$ to $86.06 \%$ for iodine, respectively. Additionally, the biosorption capacities of phenanthrene and iodine decreased from 2111.7 to $547.9 \mathrm{mg} \mathrm{kg}^{-1}$ and from 151840 to $73408 \mathrm{mg} \mathrm{kg}^{-1}$, respectively (Fig. 2b). The decreasing capacity with increasing dosage could mainly be related to the number of available binding functional groups and sites on the biosorbent due to aggregation. ${ }^{24}$ Similar trends had been observed for the biosorption of metals, dyes, uranium and organic compounds onto several biosorbents. ${ }^{17,21,38}$ In addition, the biosorption processes of phenanthrene and iodine were found to reach their optimum conditions at the dosage of $0.75 \mathrm{~g} \mathrm{~L}^{-1}$ (Fig. 2a), where the biosorption capacities caught 900 and $11600 \mathrm{mg} \mathrm{kg}^{-1}$, respectively.
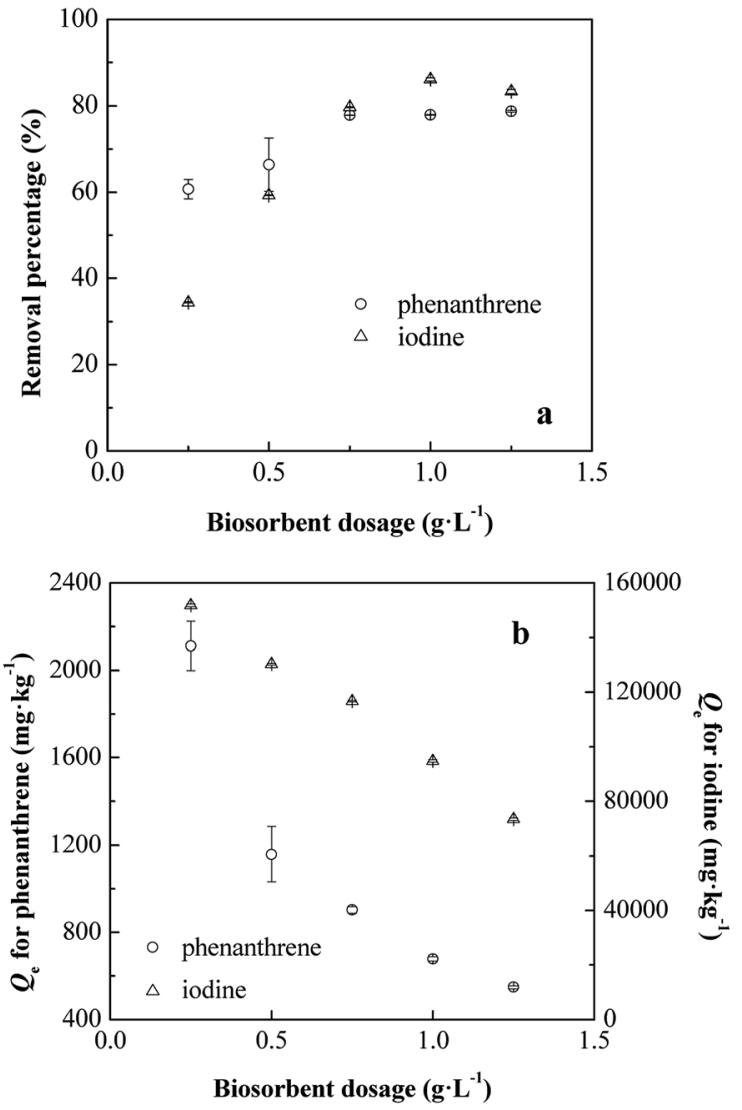

Fig. 2 Effect of biosorbent dose on the biosorption removal (a) and sorption capacity (b) of phenanthrene and iodine. Open circles represent the sorption of phenanthrene and open triangles represent the sorption of iodine.

Effects of contact time. The influence of contact time on the biosorption capacity of phenanthrene and iodine in single and binary systems were illustrated in Fig. 3. Results showed that the biosorbed phenanthrene and iodine increased with contact time up to proximately 480 minutes, after which maximal biosorption capacities or equilibrium biosorption were reached. The graduated slow-down of sorption, and finally equilibrium, were mainly due to the decrease of available sites for sorption or saturation of functional bonds. ${ }^{40}$ Therefore, 480 minutes was selected as the optimum contact time for all further experiments.

According to Fig. 3, the maximum biosorption amounts of phenanthrene by SIBB were around $1363.8 \mathrm{mg} \mathrm{kg}{ }^{-1}$ and $1494.0 \mathrm{mg} \mathrm{kg}^{-1}$ in single and binary systems and were $204020 \mathrm{mg} \mathrm{kg}^{-1}$ and $212320 \mathrm{mg} \mathrm{kg}^{-1}$ for iodine in single and binary systems, respectively. The biosorption of HOCs such as phenanthrene onto biomass mainly via hydrophobic interaction due to the presence of aliphatic carbons and aromatic structures, which have been extensively studied. ${ }^{34,41,42}$ Choung et al. proposed a possible mechanism for the sorption iodine species onto natural organic matters based on XANES spectra. ${ }^{8}$ The uptake of iodine associated with the formation of intermediate iodine species through oxidation by quinones and ketones of the black carbon. In the present study, as shown in the FTIR spectra (Fig. 1), there are quinones $(\mathrm{C}=\mathrm{O}$ of aromatic 


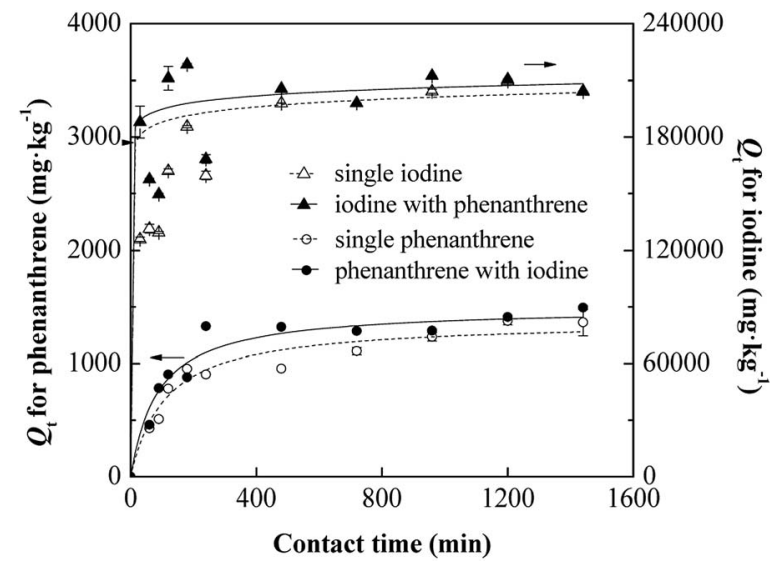

Fig. 3 Effect of contact time on the biosorption of phenanthrene and iodine in single and binary systems. Open circles with dashes represent the sorption of phenanthrene in single condition. Solid circles with a solid line represent the sorption of phenanthrene in binary condition. Open triangles with dashes represent the sorption of iodine in single condition. Solid triangles with a solid line represent the sorption of iodine in binary condition.

carbon, $\left.1650 \mathrm{~cm}^{-1}\right)$ and ketones $\left(\mathrm{C}=\mathrm{O}, 1720 \mathrm{~cm}^{-1}\right)$ groups present in the SIBB material, which mainly contribute to the sorption of iodine. Therefore, the SIBB material showed relatively large sorption capacities for both phenanthrene and iodine. Furthermore, the results indicated that the co-existence of iodine or phenanthrene enhanced the biosorption of phenanthrene and iodine in the binary conditions. The synergistic effect on phenanthrene and iodine biosorption could be attributed to the specific bonding between the iodine molecules and carbon atoms of polycyclic aromatic hydrocarbons. ${ }^{8}$

Phenanthrene and iodine biosorption in various $\mathrm{pH}$ solutions. The $\mathrm{pH}$ of a solution is one of the most important parameters affecting the biosorption process because $\mathrm{pH}$ primarily affects the surface properties of the biosorbent and the chemical property of pollutants. ${ }^{18,40}$ A wide range of $\mathrm{pH}$ (310) was used to examine the influence of $\mathrm{pH}$ on the biosorption capacity of phenanthrene and iodine in single and binary systems. As shown in Fig. 4, the biosorption capacity of phenanthrene was not obviously affected by $\mathrm{pH}$, regardless of the presence or absence of iodine. The biosorption of hydrophobic organic compounds such as phenanthrene by inactivated bacterial biomass was considered to be a result of the partition mechanism to hydrophobic surfaces. ${ }^{31}$ The partition process was insensitive to the change of solution $\mathrm{pH}$; therefore, the biosorption capacity kept a relative stable value (1077-1321 $\mathrm{mg} \mathrm{kg}^{-1}$ ) in various $\mathrm{pH}$ solutions. However, the biosorption capacity of iodine was strongly affected by $\mathrm{pH}$ especially higher $\mathrm{pH}$, as shown in Fig. 4. The biosorption capacity of iodine increased with increasing $\mathrm{pH}$ and reached maximum at a pH of 6.0 in both single and binary conditions. In the single iodine condition, the biosorption capacity dramatically decreased when the $\mathrm{pH}$ was higher than 7.0. However, the presence of phenanthrene postponed the slump point of the biosorption efficiency, up to $\mathrm{pH}=9.0$, which may extend the practical application.

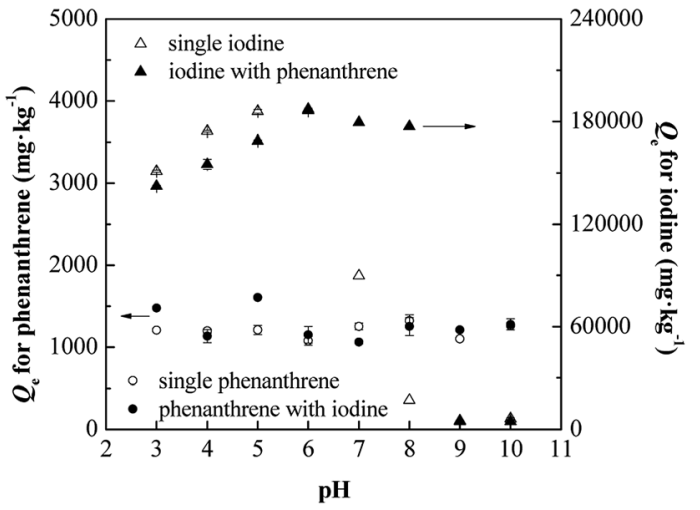

Fig. 4 Effect of solution $\mathrm{pH}$ on the biosorption of phenanthrene and iodine in single and binary systems. Open circles represent the sorption of phenanthrene in single condition. Solid circles represent the sorption of phenanthrene in binary condition. Open triangles represent the sorption of iodine in single condition. Solid triangles represent the sorption of iodine in binary condition.

Effect of ionic strength. Generally, solution chemical conditions such as ionic strength could affect the biosorption efficiency. Fig. 5 showed the effect of ionic strength at a range of $0-0.5 \mathrm{~mol} \mathrm{~L}^{-1}$ of $\mathrm{CaCl}_{2}$ on the biosorption of phenanthrene and iodine by inactivated SIBB. It could be seen that the presence of $\mathrm{CaCl}_{2}$ affected the biosorption of both contaminants in the single condition, in accord with results reported by Mahmoud et al. ${ }^{\mathbf{4 3}}$ However, there was no obvious difference at various ionic strength conditions for binary systems, as shown in Table 1. The coexisting iodine or phenanthrene may act as a "buffer" to reduce the influence on biosorption by ion strength under various environmental conditions.

\subsection{Kinetics modelling}

To evaluate the rate of phenanthrene and iodine biosorption in single or binary conditions and to examine the diffusion mechanism involved during the biosorption process, the

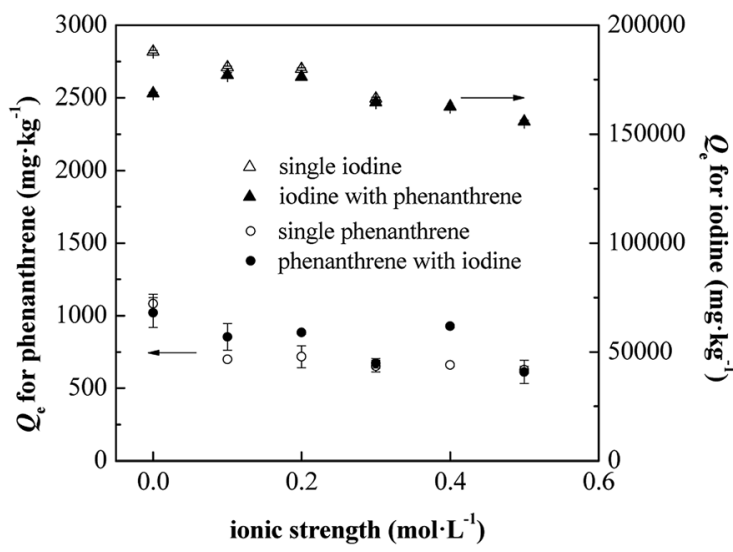

Fig. 5 Effect of ionic strength on the biosorption of phenanthrene and iodine in single and binary systems. Open circles represent the sorption of phenanthrene in single condition. Solid circles represent the sorption of phenanthrene in binary condition. Open triangles represent the sorption of iodine in single condition. Solid triangles represent the sorption of iodine in binary condition. 
Table 1 Significant difference analysis (standard $t$ test) for the biosorption capacity of phenanthrene and iodine for SIBB under different ionic strength

\begin{tabular}{|c|c|c|c|c|}
\hline$t$ & $4.385^{a}$ & 1.865 & $2.909^{a}$ & 2.168 \\
\hline$P_{0.05}^{b}$ & 2.365 & 2.365 & 2.365 & 2.365 \\
\hline
\end{tabular}

obtained dynamic experimental data was fitted with several kinetic models, such as the Morris-Weber model, Lagergren model and pseudo-second-order model. The applicability of these kinetic models was determined by the correlation coefficients $\left(R^{2}\right)$, as well as the biosorption capacity as suggested by Kausar et al. ${ }^{28}$

The calculated values of $K_{\mathrm{id}}, k_{1}, k_{2}, Q_{\mathrm{e}}$ and $h$ are listed in Table 2. As exhibited in Fig. 6, the biosorption of phenanthrene and iodine in both single and binary conditions were superbly suitable for the pseudo-second-order kinetic model in contrast to the Morris-Weber model and pseudo-first-order model (shown in Table 2). The theoretical biosorption capacities calculated from the pseudo-second-order model (1.444 and $1.458 \mathrm{mg} \mathrm{g}^{-1}$ for phenanthrene, and 212.3 and $212.8 \mathrm{mg} \mathrm{g}^{-1}$ for iodine, respectively) were very close to the experimental biosorption capacities $\left(1.364\right.$ and $1.490 \mathrm{mg} \mathrm{g}^{-1}$ for phenanthrene, and 204.0 and $212.3 \mathrm{mg} \mathrm{g}^{-1}$ for iodine, respectively). The applicability of pseudo-second-order model to the experimental data suggested that chemisorption was the dominant ratelimiting factor in controlling phenanthrene and iodine biosorption on SIBB. ${ }^{28}$

The biosorption rates of phenanthrene and iodine in single and binary conditions were compared, and results showed that the presence of co-contaminants accelerated the biosorption process. In binary conditions, the pseudo-second-order biosorption rates for phenanthrene and iodine increased from 0.005441 to $0.009825 \mathrm{~g} \mathrm{mg}^{-1} \mathrm{~min}^{-1}$ and from 0.000114 to $0.000223 \mathrm{~g} \mathrm{mg}^{-1} \mathrm{~min}^{-1}$, respectively. The initial biosorption rate $h\left(\mathrm{mg} \mathrm{g}^{-1} \min ^{-1}\right)$ of the pseudo-second-order model was calculated as follows and listed in Table 2:

$$
h=k_{2} Q_{\mathrm{e}}^{2}
$$

The initial rate might be a better parameter to evaluate the sorption rate considering the importance of an initial fast process in biosorption. Similar to the pseudo-second-order rate $\left(k_{2}\right)$, we could find a much larger initial rate $(h)$ for both phenanthrene and iodine in binary conditions. In the binary system, improvements of $88.3 \%$ and $97.1 \%$ for phenanthrene and iodine, respectively, were achieved compared to single biosorption.

\subsection{Isothermal modelling}

The applications of the linear, Langmuir, Freundlich, D-R and Temkin models for the biosorption of phenanthrene and iodine in single and binary conditions by inactivated SIBB were explored, and the regression parameters are listed in Table 3. Comparing to Freundlich, D-R and Temkin models, biosorption of phenanthrene on SIBB fits well with the linear equation, while biosorption data of iodine fits well with the Langmuir model.

Table 2 Kinetic constants for phenanthrene and iodine in single or binary conditions by bacterial biomass

\begin{tabular}{|c|c|c|}
\hline Morris-Weber model & $K_{\mathrm{id}}, \mathrm{mg} \mathrm{kg}^{-1} \mathrm{~min}^{-1 / 2}$ & $R^{2}$ \\
\hline Phenanthrene (single) & 32.46 & 0.8830 \\
\hline $\begin{array}{l}\text { Phenanthrene } \\
\text { (binary) }\end{array}$ & 33.13 & 0.7681 \\
\hline Iodine (single) & 2562 & 0.8011 \\
\hline Iodine (binary) & 1267 & 0.3099 \\
\hline \multicolumn{3}{|c|}{${ }^{a}$ Single condition. ${ }^{b}$ Binary condition. } \\
\hline Lagergren model & $k_{1}, \min ^{-1}$ & $R^{2}$ \\
\hline Phenanthrene (single) & 0.0008186 & 0.7770 \\
\hline $\begin{array}{l}\text { Phenanthrene } \\
\text { (binary) }\end{array}$ & 0.0003880 & 0.2608 \\
\hline Iodine (single) & 0.001170 & 0.8084 \\
\hline Iodine (binary) & 0.000418 & 0.1383 \\
\hline
\end{tabular}

Pseudo-second-order $\quad h, \mathrm{mg}$ model $k_{2}, \mathrm{~g} \mathrm{mg}^{-1} \min ^{-1} Q_{\mathrm{e}}, \mathrm{mg} \mathrm{g}^{-1} \mathrm{~g}^{-1} \min ^{-1} R^{2}$

Type $1 \mathrm{t} / Q_{t}=1 /\left(k_{2} Q_{\mathrm{e}}{ }^{2}\right)+\left(1 / Q_{\mathrm{e}}\right) t \boldsymbol{t} / Q_{t} \sim t$

Phenanthrene $(\mathrm{S})^{a} \quad 0.00544$ $\begin{array}{llll}0.00544 & 1.444 & 0.0111 & 0.9920\end{array}$ $\begin{array}{lllll}\text { Iodine (S) } & 0.00011 & 212.3 & 5.1308 & 0.9986\end{array}$ $\begin{array}{lllll}\text { Iodine (B) } & 0.00022 & 212.8 & 10.111 & 0.9978\end{array}$

Type $21 / Q_{t}=1 / Q_{\mathrm{e}}+1 / k_{2} Q_{\mathrm{e}}^{2}(1 / t) 1 / Q_{t} \sim 1 / t$

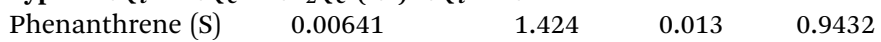
$\begin{array}{lllll}\text { Phenanthrene (B) } & 0.00714 & 1.473 & 0.016 & 0.8967\end{array}$ $\begin{array}{lllll}\text { Iodine (S) } & 0.00025 & 194.2 & 9.372 & 0.7234\end{array}$ $\begin{array}{lllll}\text { Iodine (B) } & 0.00022 & 211.9 & 9.728 & 0.5128\end{array}$

Type $3 Q_{t}=Q_{\mathrm{e}}-1 / k_{2} Q_{\mathrm{e}}\left(Q_{t} / t\right) Q_{t} \sim Q_{t} / t$ $\begin{array}{lllll}\text { Phenanthrene (S) } & 0.00920 & 1.342 & 0.017 & 0.8025\end{array}$ $\begin{array}{lllll}\text { Phenanthrene (B) } & 0.00890 & 1.449 & 0.019 & 0.6054\end{array}$ $\begin{array}{lllll}\text { Iodine (S) } & 0.00023 & 198.1 & 8.846 & 0.6883\end{array}$ $\begin{array}{lllll}\text { Iodine (B) } & 0.00029 & 208.9 & 12.58 & 0.3183\end{array}$

Type $4 Q_{t} / t=k_{2} Q_{\mathrm{e}}{ }^{2}-k_{2} Q_{\mathrm{e}} Q_{\mathrm{t}} Q_{t} / t \sim Q_{t}$ $\begin{array}{lllll}\text { Phenanthrene (S) } & 0.00696 & 1.422 & 0.014 & 0.8025\end{array}$ $\begin{array}{lllll}\text { Phenanthrene (B) } & 0.00468 & 1.670 & 0.013 & 0.6054\end{array}$ $\begin{array}{lllll}\text { Iodine (S) } & 0.00015 & 209.2 & 6.432 & 0.6883\end{array}$ $\begin{array}{lllll}\text { Iodine (B) } & 0.00008 & 241.5 & 4.630 & 0.3183\end{array}$ 

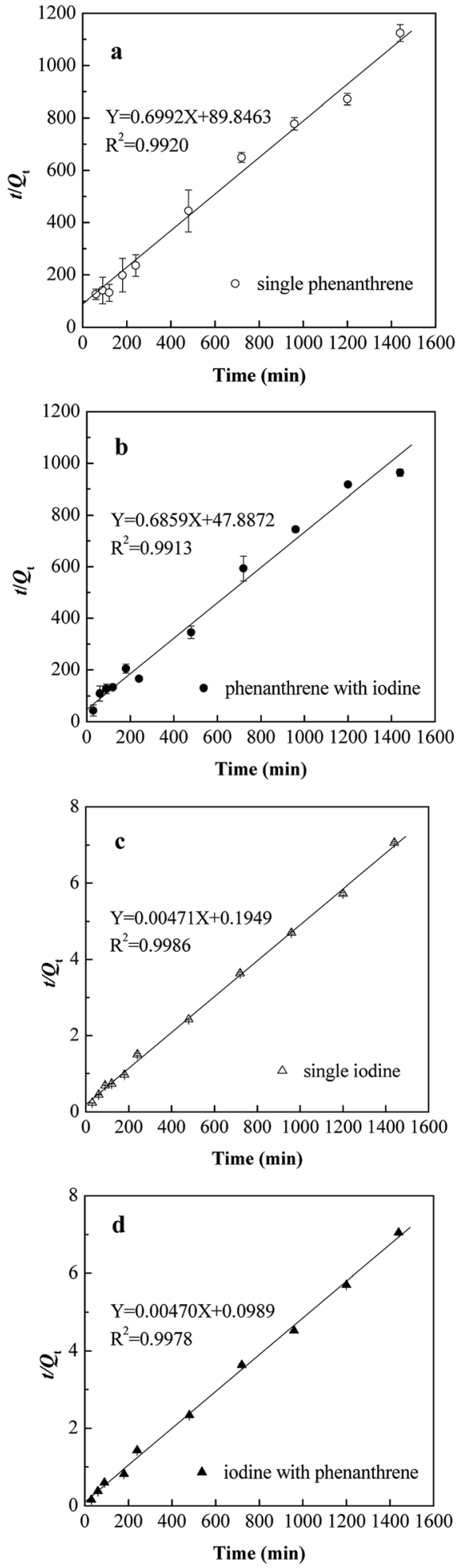

Fig. 6 Sorption kinetics for phenanthrene and iodine in single or binary conditions by bacterial biomass stimulated by the pseudosecond-order model. Open circles represent the sorption of phenanthrene in single condition (a). Solid circles represent the sorption of phenanthrene in binary condition (b). Open triangles represent the sorption of iodine in single condition (c). Solid triangles represent the sorption of iodine in binary condition (d).
Table 3 Isotherm sorption constants for phenanthrene and iodine in single or binary conditions by bacterial biomass

\begin{tabular}{|c|c|c|c|c|}
\hline Linear model & \multicolumn{3}{|c|}{$K_{\mathrm{d}}, \mathrm{L} \mathrm{kg}^{-1}$} & $R^{2}$ \\
\hline Phenanthrene $(\mathrm{S})^{a}$ & \multicolumn{3}{|c|}{$6892.4 \pm 10.95$} & 0.9999 \\
\hline Phenanthrene $(\mathrm{B})^{b}$ & \multicolumn{3}{|c|}{$9283.7 \pm 192.3$} & 0.9962 \\
\hline Iodine $(\mathrm{S})$ & \multicolumn{3}{|c|}{$1443.7 \pm 702.4$} & 0.3496 \\
\hline Iodine (B) & \multicolumn{3}{|c|}{$1359.7 \pm 736.5$} & 0.2864 \\
\hline \multicolumn{5}{|c|}{${ }^{a}$ Single condition. ${ }^{b}$ Binary condition. } \\
\hline Langmuir model & $K_{\mathrm{L}}, \mathrm{L} \mathrm{mg}^{-1}$ & \multicolumn{2}{|l|}{$Q_{\mathrm{m}}, \mathrm{mg} \mathrm{g}^{-1}$} & $R^{2}$ \\
\hline Phenanthrene (S) & - & - & - & 0.2153 \\
\hline Phenanthrene (B) & - & - & - & 0.0029 \\
\hline Iodine $(S)$ & 0.2325 & 216.9 & $0.044-0.387$ & 0.9953 \\
\hline Iodine (B) & 0.4813 & 199.6 & $0.023-0.234$ & 0.9987 \\
\hline Freundlich model & \multicolumn{2}{|c|}{$K_{\mathrm{F}}, \mathrm{L} \mathrm{kg}^{-1}$} & $n$ & $R^{2}$ \\
\hline Phenanthrene (S) & \multicolumn{2}{|c|}{9034.4} & 0.8949 & 0.9854 \\
\hline Phenanthrene (B) & \multicolumn{2}{|c|}{7856.0} & 1.0082 & 0.9394 \\
\hline Iodine $(\mathrm{S})$ & \multicolumn{2}{|c|}{146892} & 13.550 & 0.8757 \\
\hline Iodine (B) & \multicolumn{2}{|c|}{162630} & 25.252 & 0.8530 \\
\hline D-R model & $\beta, \mathrm{mol}^{2} \mathrm{~J}^{-2}$ & \multicolumn{2}{|c|}{$Q_{\mathrm{m}}, \mathrm{mol} \mathrm{g}^{-1} \quad R^{2}$} & $E, \mathrm{~kJ} \mathrm{~mol}^{-1}$ \\
\hline Phenanthrene (S) & $1.19 \times 10^{-8}$ & 237.56 & 0.9918 & \\
\hline Phenanthrene (B) & $1.01 \times 10^{-8}$ & 143.87 & 0.9327 & 36 \\
\hline Iodine $(\mathrm{S})$ & $2.48 \times 10^{-9}$ & 814.77 & 0.7518 & \\
\hline Iodine (B) & $1.32 \times 10^{-9}$ & 769.40 & $0.7313 \quad 19$ & \\
\hline Temkin model & $b, \mathrm{~kJ} \mathrm{~m}$ & $\mathrm{ol}^{-1}$ & $\mathrm{~kg}^{-1}$ & $R^{2}$ \\
\hline Phenanthrene (S) & 0.6351 & 625 & 7.4 & 0.9302 \\
\hline Phenanthrene (B) & 0.7834 & 852 & 5.4 & 0.8319 \\
\hline Iodine (S) & 0.0448 & 5.9 & $3 \times 10^{6}$ & 0.8537 \\
\hline Iodine (B) & 0.0851 & 7.3 & $8 \times 10^{11}$ & 0.8431 \\
\hline
\end{tabular}

Biosorption of organic pollutants to biomass could involve surface sorption, chemical reactions and partitioning processes. The well-fit with linear model for phenanthrene (Fig. 7a and b) indicated that the primary mechanism of phenanthrene biosorption was partitioning. This was consistent with the previous studies about dead or inactivated bacterial and fungal biomass ${ }^{31,41}$ and the FTIR results. In the present study, the FTIR spectrum showed that the SIBB was abundant with saturated $\left(3000-2850 \mathrm{~cm}^{-1},-\mathrm{CH}_{3},-\mathrm{CH}_{2}-\right)$ and unsaturated (near $980 \mathrm{~cm}^{-1}, \mathrm{C}=\mathrm{C}$ ) aliphatic carbon and aromatic structure $\left(1650 \mathrm{~cm}^{-1}\right)$, which provided effective binding sites for phenanthrene. Calculated partition coefficients $\left(K_{\mathrm{d}}\right)$ of phenanthrene in single and binary conditions were 6892.4 and $9283.7 \mathrm{~L} \mathrm{~kg}^{-1}$, respectively. These results showed that SIBB had a high affinity for phenanthrene compared with reported data. ${ }^{31,41}$ In addition, the presence of iodine highly enhanced the partition coefficient of phenanthrene with an increase of $34.7 \%$. A specific binding would occur between iodine and carbon atoms in aromatic hydrocarbons according to the mechanism illustrated by Choung et al. ${ }^{8}$ The interaction or binding of phenanthrene with iodine was theoretically possible. As partitioning was the dominant mechanism for biosorption of phenanthrene, the biosorption of iodine on SIBB should not occupy the partition 

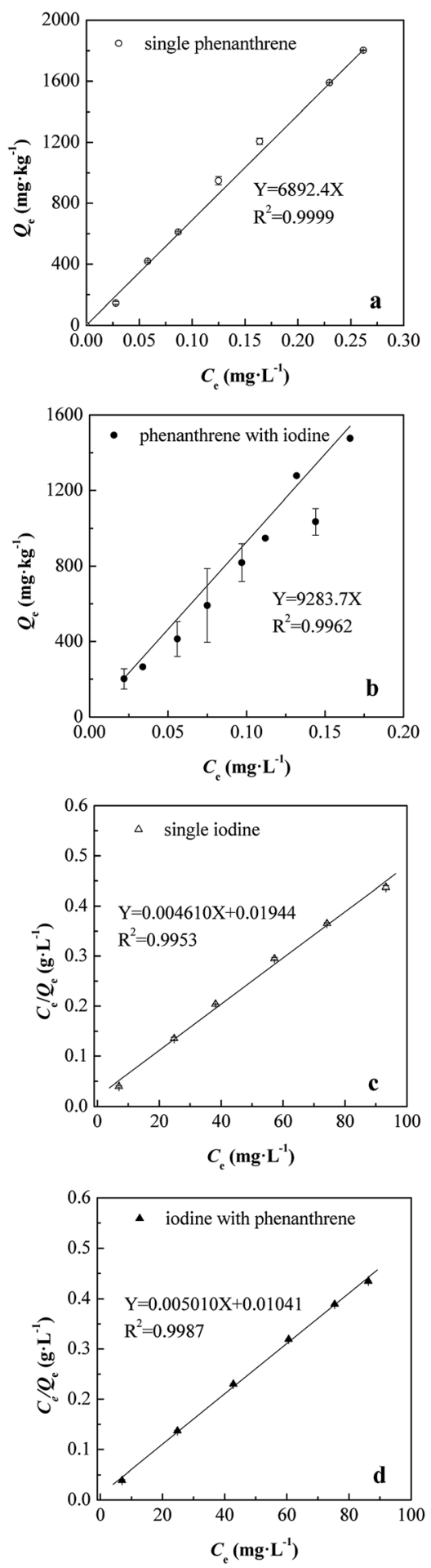

Fig. 7 Isothermal sorption for phenanthrene and iodine in single or binary conditions by bacterial biomass simulated by the Linear model (for phenanthrene, (a) and (b)) and by the Langmuir model (for iodine, (c) and (d)). Open circles represent the sorption of phenanthrene in single condition (a). Solid circles represent the sorption of phenanthrene in binary condition (b). Open triangles represent the sorption of iodine in single condition (c). Solid triangles represent the sorption of iodine in binary condition (d). site for phenanthrene. Therefore, the sorbed iodine molecules might provide extra chemical bonding sites for the biosorption of phenanthrene, leading to a significant increase in sorption affinity for phenanthrene of SIBB.

The partition coefficient $\left(K_{\mathrm{d}}\right)$ is a useful parameter to evaluate the distribution of organic compounds between solid and solution phases, and hence, their fate and mobility in the environment. Based on $K_{\mathrm{d}}$ values, the affinity of organic pollutants to biosorbents or solid phases from the aqueous phase can be estimated. The determined $\log K_{\mathrm{d}}$ values of phenanthrene by SIBB were 3.84 and 3.97 for single and bisolute conditions, respectively. These values were much higher than those of soil-water systems (1.48-2.30), due to the higher carbon content of SIBB. ${ }^{44,45}$ The $\log K_{\mathrm{d}}$ of phenanthrene valued within a wide range of 2.98 to 4.76 for natural organic matter, microbiological biomass and plant residues, as summarized by Chen et al. ${ }^{46}$ The $\log K_{\mathrm{d}}$ values obtained in this study were higher than live tissues such as wood chips (3.40), plant roots (3.32-3.70), tender tea leaves $(3.52-3.54)^{46}$ and algae and planktons (3.36-3.89). ${ }^{42}$ Additionally, these values were lower than the cuticle of plants (4.21-4.73) and humic acid (4.45). Therefore, bacterial biosorption may play an important role in the fate of phenanthrene in soils and surface water. ${ }^{41}$

The sorption mechanism of iodine onto biomass could be proposed to be specific bonding with carbon atoms according to the mechanisms illustrated by Choung et al. ${ }^{8}$ Accordingly, the aromatic carbon in organic matter participated in the oxidation of iodine to some form of intermediates, facilitating the formation of aromatic carbon-iodine bonds rather than aliphatic carbon-iodine bonds. According to the postulates of the Langmuir model, a good fit would indicate that the monolayer chemical biosorption occurred at a given number of specific homogenous sites due to intermolecular forces. ${ }^{21}$ Affinity parameter $K_{\mathrm{L}}$ values for iodine were 0.2325 and $0.4813 \mathrm{~L}$ $\mathrm{mg}^{-1}$ (232 500 and $481300 \mathrm{~L} \mathrm{~kg}^{-1}$ ), as illustrated in Fig. 7c and d. A significant increase of the $K_{\mathrm{L}}$ value of $107.0 \%$ in the presence of phenanthrene was found compared to the single iodine condition. As mentioned above, the biosorption of phenanthrene followed the partition mechanism and did not occupy the binding sites for iodine. Furthermore, the co-solute (phenanthrene) improved the sorption affinity of SIBB by introducing active binding sites and forming new functional groups that favoured iodine biosorption, which could be attributed to their interaction. $^{8}$

The separation factor or equilibrium parameter constant $\left(R_{\mathrm{L}}\right)$ was an important characteristic of the Langmuir isotherm and was represented as follows:

$$
R_{\mathrm{L}}=\frac{1}{1+K_{\mathrm{L}} C_{\mathrm{i}}}
$$

The separation factors $\left(R_{\mathrm{L}}\right)$ were $0.044-0.387$ and $0.023-0.234$ following the range of $0-1.0$, indicating a favourable biosorption of iodine, as listed in Table $3 .^{21}$ 


\section{Conclusions}

The present work showed that soil indigenous bacterial biomass was successfully applied for the simultaneous biosorption of phenanthrene and iodine from aqueous solutions. Synergistic effects were also found in binary conditions. The pseudo-second-order dynamic model agreed very well for the biosorption of phenanthrene and iodine onto SIBB. Calculated pseudo-second-order rates $\left(k_{2}\right)$ illustrated that the co-solute accelerated the biosorption process, with improvements of $80.6 \%$ and $95.6 \%$ for phenanthrene and iodine, respectively. The SIBB showed strong affinity with both phenanthrene and iodine, with a partition coefficient $K_{\mathrm{d}}$ (Linear model) of $6892.4 \mathrm{~L}$ $\mathrm{kg}^{-1}$ for phenanthrene and affinity parameter $K_{\mathrm{L}}$ (Langmuir model) of $232500 \mathrm{~L} \mathrm{~kg}^{-1}$ for iodine. The presence of co-solute illustrated a synergistic effect on biosorption due to intermolecular forces between phenanthrene and iodine, enhancing the $K_{\mathrm{d}}$ by $34.7 \%$ for phenanthrene and $K_{\mathrm{L}}$ by $107.0 \%$ for iodine, respectively. Affecting factors were also tested to optimize biosorption parameters. Ideal conditions for the biosorption process included a $\mathrm{pH}$ of the solution of 6.0 and a $0.75 \mathrm{~g} \mathrm{~L}^{-1}$ biosorbent dosage within a 480 minutes time contact between the biosorbent and sorbates. The ionic strength significantly affected the biosorption of both phenanthrene and iodine in single condition, while no obvious influences were found in the binary conditions.

\section{Conflicts of interest}

There are no conflicts to declare.

\section{Acknowledgements}

This work was supported by the National Natural Science Foundation of China (21407037, 21878064, and 41271249), and Project of the Natural Science Foundation of Zhejiang Province (LY19B070009).

\section{References}

1 K. Hirose, 2011 Fukushima Dai-ichi nuclear power plant accident: summary of regional radioactive deposition monitoring results, J. Environ. Radioact., 2012, 111, 13-17.

2 P. S. Rose, R. L. Swanson and J. K. Cochran, Medicallyderived ${ }^{131}$ I in municipal sewage effluent, Water Res., 2012, 46, 5663-5671.

3 G. Lefèvre, J. Bessière, J. J. Ehrhardt and A. Walcarius, Immobilization of iodide on copper(I) sulfide minerals, $J$. Environ. Radioact., 2003, 70, 73-83.

4 C. Xu, S. Zhang, Y. F. Ho, E. J. Miller, K. A. Roberts, H. P. Li, K. A. Schwehr, S. Otosaka, D. I. Kaplan, R. Brinkmeyer, C. M. Yeager and P. H. Santischi, Is soil natural organic matter a sink or source for mobile radioiodine $\left({ }^{129} \mathrm{I}\right)$ at the Savannah River Site?, Geochim. Cosmochim. Acta, 2011, 75, 5716-5735.

5 L. Liu, W. Liu, X. L. Zhao, D. M. Chen, R. S. Cai, W. Y. Yang, S. Komarneni and D. J. Yang, Selective capture of iodide from solutions by microrosette-like $\delta-\mathrm{Bi}_{2} \mathrm{O}_{3}, A C S$ Appl. Mater. Interfaces, 2014, 6, 16082-16090.

6 V. S. Kazakov, E. P. Demidchik and L. N. Astakhova, Thyroid cancer after Chernobyl, Nature, 1992, 359, 21-22.

7 H. A. Robertson and I. R. Falconer, Accumulation of radioactive iodine in thyroid glands subsequent to nuclear weapon tests and the accident at windscale, Nature, 1959, 184, 1699-1702.

8 S. Choung, W. Um, M. Kim and M. G. Kim, Uptake mechanism for iodine species to black carbon, Environ. Sci. Technol., 2013, 47, 10349-10355.

9 C. Xu, E. J. Miller, S. Zhang, H. P. Li, Y. F. Ho, K. A. Schwehr, D. I. Kaplan, S. Otosaka, K. A. Roberts, R. Brinkmeyer, C. M. Yeager and P. H. Santschi, Sequestration and remobilization of radioiodine $\left({ }^{129} \mathrm{I}\right)$ by soil organic matter and possible consequences of the remedial action at Savannah River Site, Environ. Sci. Technol., 2011, 45, 99759983.

10 M. L. Schlegel, P. Peiller, F. Mercier-Bion, N. Barre and V. Moulin, Molecular environment of iodine in naturally iodinated humic substances: Insight from X-ray absorption spectroscopy, Geochim. Cosmochim. Acta, 2006, 70, 55365551.

11 R. Jaffé, Fate of hydrophobic organic pollutants in the aquatic environment: A review, Environ. Pollut., 1991, 69(23), 237-257.

12 J. K. Mwangi, W. J. Lee, L. C. Wang, P. J. Sung, L. S. Fang, Y. Y. Lee and G. P. Chang-Chien, Persistent organic pollutants in the Antarctic coastal environment and their bioaccumulation in penguins, Environ. Pollut., 2016, 216, 924-934.

13 K. Chojnacka, Biosorption and bioaccumulation - the prospects for practical applications, Environ. Int., 2010, 36, 299-307.

14 Y. Liu and Y. J. Liu, Biosorption isotherms, kinetics and thermodynamics, Sep. Purif. Technol., 2008, 61, 229-242.

15 K. Vijayaraghavan and Y. S. Yun, Bacterial biosorbents and biosorption, Biotechnol. Adv., 2008, 26, 266-291.

16 A. A. Azzaz, S. Jellali, R. Souissi, K. Ergaieg and L. Bousselmi, Alkaline-treated sawdust as an effective material for cationic dye removal from textile effluents under dynamic conditions: breakthrough curve prediction and mechanism exploration, Environ. Sci. Pollut. Res., 2017, 24, 18240-18256.

17 M. J. vPuchana-Rosero, E. C. Lima, S. Ortiz-Monsalve, B. Mella, D. Costa, E. Poll and M. Gutterres, Fungal biomass as biosorbent for the removal of Acid Blue 161 dye in aqueous solution, Environ. Sci. Pollut. Res., 2017, 24, 4200-4209.

18 S. Rangabhashiyam, E. Suganya, A. V. Lity and N. Selvaraju, Equilibrium and kinetics studies of hexavalent chromium biosorption on a novel green macroalgae Enteromorpha sp, Res. Chem. Intermed., 2016, 42, 1275-1294.

19 N. Saranya, A. Abhishek, V. Sivasubramanian and N. Selvaraju, Hexavalent chromium removal from simulated and real effluents using Artocarpus heterophyllus peel biosorbent - batch and continuous studies, J. Mol. Liq., 2018, 265, 779-1294. 
20 S. M. Ge and S. C. Ge, Simultaneous Cr(VI) reduction and $\mathrm{Zn}$ (II) biosorption by Stenotrophomonas sp. and constitutive expression of related genes, Biotechnol. Lett., 2016, 38, 877884.

21 M. E. Mahmoud, G. M. E. Zokm, A. E. M. Farag and M. S. Abdelwahab, Assessment of heat-inactivated marine Aspergillus flavus as a novel biosorbent for removal of $\mathrm{Cd}(\mathrm{II}), \mathrm{Hg}(\mathrm{II})$, and $\mathrm{Pb}(\mathrm{II})$ from water, Environ. Sci. Pollut. Res., 2017, 24, 18218-18228.

22 M. S. G. Nandagopal, R. Antony, N. Sreekumar and N. Selvaraju, Experimental exploration on degradation of Organe G 16 and azo dye by novel Pseudoalteromonas sp. and its enzyme activity, Arabian J. Sci. Eng., 2015, 40, 10051013.

23 V. Karthik, K. Saravanan, E. Nakkeeran and N. Selvaraju, Biosorption of Turquoise Blue dye from aqueous solution by dried fungal biomass (Trichoderma harzianum) - kinetic, isotherm and thermodynamic studies, Desalin. Water Treat., 2017, 74, 362-370.

$24 \mathrm{Z}$. Aksu and J. Yener, A comparative adsorption/biosorption study of mono-chlorinated phenols onto various sorbents, Waste Manag., 2001, 21, 695-702.

25 L. L. Bai, H. C. Xu, C. H. Wang, J. C. Deng and H. L. Jiang, Extracellular polymeric substances facilitate the biosorption of phenanthrene on cyanobacteria Microcystis aeruginosa, Chemosphere, 2016, 162, 172-180.

26 S. Luo, L. L. Li, A. W. Chen, Q. R. Zeng, H. Xia and J. D. Gu, Biosorption of diethyl phthalate ester by living and nonliving Burkholderia cepacia and the role of its cell surface components, Chemosphere, 2017, 178, 187-196.

27 E. Bağda, M. Tuzen and A. Sarı, Equilibrium, thermodynamic and kinetic investigations for biosorption of uranium with green algae (Cladophora hutchinsiae), $J$. Environ. Radioact., 2017, 175-176, 7-14.

28 A. Kausar, H. N. Bhatti and G. MacKinnon, Equilibrium, kinetic and thermodynamic studies on the removal of U(VI) by low cost agricultural waste, Colloids Surf., B, 2013, 111, 124-133.

29 D. Zhang and L. Z. Zhu, Controlling microbiological interfacial behaviors of hydrophobic organic compounds by surfactants in biodegradation process, Front. Environ. Sci. Eng., 2014, 8(3), 305-315.

30 N. Yee, L. G. Benning, V. R. Phoenix and F. G. Ferris, Characterization of metal-cyanobacteria sorption reactions: A combined macroscopic and infrared spectroscopic investigation, Environ. Sci. Technol., 2004, 38, 775-782.

31 D. Zhang, L. Z. Zhu and F. Li, Influences and mechanisms of surfactants on pyrene biodegradation based on interactions of surfactant with a Klebsiella oxytoca strain, Bioresour. Technol., 2013, 142, 454-461.

32 L. Xiao, X. Qu and D. Q. Zhu, Biosorption of nonpolar hydrophobic organic compounds to Escherichia coli facilitated by metal and proton surface binding, Environ. Sci. Technol., 2007, 41(8), 2750-2755.
33 C. Yang, H. L. Yu, H. Jiang, C. L. Qiao and R. H. Liu, An engineered microorganism can simultaneously detoxify cadmium, chlorpyrifos, and $\gamma$-hexachlorocyclohexane, $J$. Basic Microbiol., 2016, 56, 820-826.

34 D. Zhang, L. Lu, H. T. Zhao, M. Q. Jin, T. Lü and J. Lin, Application of Klebsiella oxytoca biomass in the biosorptive treatment of PAH-bearing wastewater: Effect of PAH hydrophobicity and implications for prediction, Water, 2018, 10, 675.

35 T. Madrakian, A. Afkhami, M. A. Zolfigol, M. Ahmadi and N. Koukabi, Application of modified silica coated magnetite nanoparticles for removal of iodine from water samples, Nano-Micro Lett., 2012, 4(1), 57-63.

36 W. J. Weber and J. C. Morris, Kinetics of adsorption on carbon from solution, J. Sanit. Eng. Div., Am. Soc. Civ. Eng., 1963, 89, 31-59.

37 H. Javadian, P. Vahedian and M. Toosi, Adsorption characteristics of $\mathrm{Ni}(\mathrm{II})$ from aqueous solution and industrial wastewater onto polyaniline/HMS nanocomposite powder, Appl. Surf. Sci., 2013, 284, 13-22.

38 Y. S. Ho and G. McKay, Pseudo-second order model for sorption processes, Process Biochem., 1999, 34, 451-465.

39 Y. S. Ho, Second-order kinetic model for the sorption of cadmium onto tree fern: A comparison of linear and nonlinear methods, Water Res., 2006, 40, 119-125.

40 V. R. Fanaie, M. Karrabi, M. M. Amin, B. Shahnavaz and A. Fatehizadeh, Biosorption of 4-chlorophenol by dried anaerobic digested sludge: artificial neural network modeling, equilibrium isotherm, and kinetic study, Int. J. Environ. Sci. Technol., 2017, 14, 37-38.

41 B. L. Chen, Y. S. Wang and D. F. Hu, Biosorption and biodegradation of polycyclic aromatic hydrocarbons in aqueous solutions by a consortium of white-rot fungi, $J$. Hazard. Mater., 2010, 179, 845-851.

42 D. N. Zhang, C. Y. Ran, Y. Yang and Y. Ran, Biosorption of phenanthrene by pure algae and field-collected planktons and their fractions, Chemosphere, 2013, 93, 61-68.

43 M. E. Mahmoud, G. M. E. Zokm, A. E. M. Farag and M. S. Abdelwahab, Assessment of heat-inactivated marine Aspergillus flavus as a novel biosorbent for removal of $\mathrm{Cd}(\mathrm{II}), \mathrm{Hg}(\mathrm{II})$, and $\mathrm{Pb}(\mathrm{II})$ from water, Environ. Sci. Pollut. Res., 2017, 24, 18218-18288.

44 K. Yang, L. Z. Zhu and B. S. Xing, Enhanced soil washing of phenanthrene by mixed solutions of TX100 and SDBS, Environ. Sci. Technol., 2006, 40, 4274-4280.

$45 \mathrm{~W}$. J. Zhou and L. Z. Zhu, Enhanced desorption of phenanthrene from contaminated soil using anionic/ nonionic mixed surfactant, Environ. Pollut., 2007, 147, 350357.

46 B. L. Chen, M. X. Yuan and H. Liu, Removal of polycyclic aromatic hydrocarbons from aqueous solution using plant residue materials as a biosorbent, J. Hazard. Mater., 2011, 188, 436-442. 